\title{
Retirement Plans for College and University Librarians
}

Dr. Stieg is librarian, University of Southern California.

TN 1947 the A.L.A. Committee on An1 nuities, Pensions and Life Insurance requested a study of retirement provisions for librarians in colleges and universities. This study was undertaken for the purpose of discovering: (I) To what extent librarians in institutions of higher education are covered by retirement plans; (2) Under what conditions those plans are available to librarians.

The data are derived from two sources: William C. Greenough's College Retirement and Insurance Plans (New York, Columbia University Press, 1948), and a questionnaire. Greenough's book is a comprehensive and thorough analysis of the subject for four-year institutions, but it does not provide specific information regarding librarians as a group. The questionnaire, a copy of which forms Appendix I, was sent to the librarians of all continental U.S. institutions listed in the U.S. Office of Education's 1946-47 Educational Directory: Colleges and Universities. The data provided by it are summarized in Tables II-VI. Occasionally totals do not agree in these tables. Discrepancies, however, are apparent rather than real. Not all questionnaires were answered in full; in some cases one institution gave two or more answers to the same question because alternative retirement plans were available.

The figures on returns from the questionnaire are analyzed in Table I. The replies from junior colleges are so few that no conclusions can be drawn from them. This group is, therefore, omitted whenever tabulations have been combined to provide more general information. For the other types of educational institutions, however,

Table I

Replies to Questionnaire

\begin{tabular}{l|r|r|r}
\hline \hline & Sent & $\begin{array}{c}\text { Re- } \\
\text { turned }\end{array}$ & $\begin{array}{c}\text { Per } \\
\text { Cent }\end{array}$ \\
\cline { 2 - 3 } $\begin{array}{l}\text { Colleges and Universities } \\
\text { Teachers Colleges }\end{array}$ & 783 & 301 & 38 \\
Professional and Techno- & 212 & 39 & I8 \\
logical Schools & 265 & 29 & I I \\
Junior Colleges & 435 & 34 & 8 \\
\hline \multicolumn{1}{c|}{ Total } & 1695 & 403 & 23 \\
\hline
\end{tabular}

the sample seems to be reasonably reliable. If all returns except those from junior colleges are considered together, $8 \mathrm{I}$ per cent report some kind of retirement plan for their faculties. Greenough found that four out of five of the 906 institutions from which he secured information have retirement plans for the faculty. ${ }^{1}$ Other figures from the questionnaire sample also show a high degree of correspondence with comparable figures from Greenough's much larger sample. For example, Greenough's Table I reports 45.7 per cent of U.S. colleges and universities using the Teachers Insurance and Annuity Association of America plan, 22.I per cent using a publicly administered plan, and $\mathrm{I} 7.3$ per cent using some other type of plan. ${ }^{2}$ The comparable

1 Greenough, William $\mathrm{C}$., College Retirement and Insurance Plans. New York, Columbia University Press, 1948 , p. 6-7.

2 Ibid., p. 4 . 
Table II

Universities

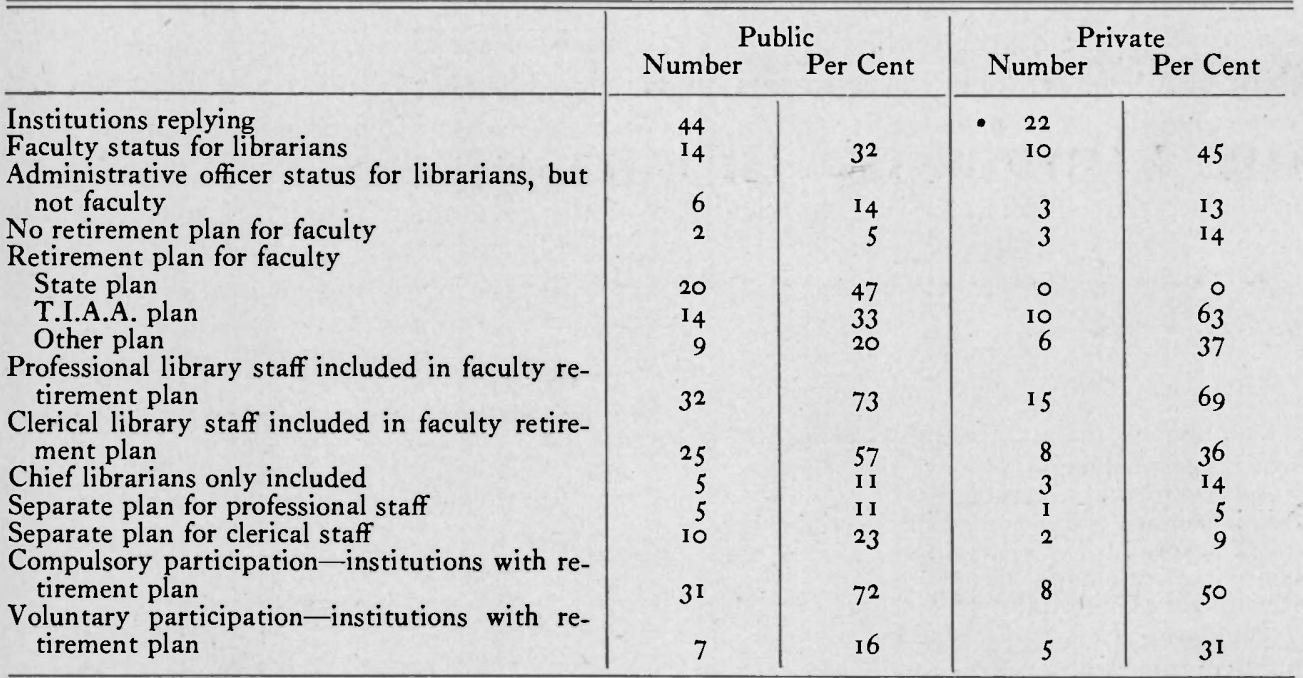

figures from the questionnaire returns are 37.0, 20.8 and I8.9 per cent.

The sample provided by the replies to the questionnaire can not, however, be considered representative of all institutions of higher education with regard to provision of retirement plans. Many of the institutions which did not reply are small or unaccredited; a very large proportion of the smaller Catholic colleges did not reply. It is probable that among these groups many more than 20 per cent have no retirement plan. Greenough came to the same conclusion for the institutions from which he could not secure information: "It may be assumed that few of them have any organized plans providing for retirement income. Careful checks of secondary information ... confirm this conclusion."

The extent to which Greenough considered his sample representative can be deduced from the two following statements: "Over 80 per cent of the colleges, covering more than 90 per cent of the teachers employed, responded to requests for

I Ibid., p. 7. information. Of the institutions that responded, about four out of five have retirement plans." ${ }_{4}$ In a summary he concludes: "Two-thirds of the colleges, universities, and state teachers colleges in the United States, employing over 85 per cent of the total number of faculty members, now have retirement plans." 5

Of the institutions which returned the questionnaire, approximately three-fourths of those with a faculty retirement plan also provide some kind of retirement income for librarians. Publicly supported institutions provide retirement plans more often than the private college or university. In an insignificant number of cases, the professional librarian is covered by a plan different from that offered the teaching staff.

The chief librarians returning the questionnaire reported a total of 3086 professional personnel. If the estimate in the A.L.A. report, Post-war Library Personnel, of 5000 professional librarians in college and university libraries is correct, ${ }^{6}$ the data

4 Ibid.

5 Ibid., p. 62 .

American Library Association Post-war Library Personnel, a Report, (Mimeographed, I944), p. 5. 
covers three-fifths of the librarians employed. For this group, retirement plans are provided for 82 per cent.

In about 55 per cent of the institutions reporting, librarians have faculty status. In another 19 per cent, they are classified as administrative officers, but not as faculty. librarian. Approximately 4I per cent of the four-year institutions reporting make provision for this class of personnel. The publicly supported university gives him the privilege most often, usually through a state or municipal plan for all clerical employees of the governmental unit. The private col-

Table III

Colleges

\begin{tabular}{|c|c|c|c|c|}
\hline & \multicolumn{2}{|c|}{ Public } & \multicolumn{2}{|c|}{ Private } \\
\hline & Number & er Cent & Number & er Cent \\
\hline $\begin{array}{l}\text { Institutions replying } \\
\text { Faculty status for librarians } \\
\text { Administrative officer status for librarians, but } \\
\text { not faculty } \\
\text { No retirement plan for faculty } \\
\text { Retirement plan for faculty } \\
\text { State plan } \\
\text { T.I.A.A. plan } \\
\text { Other plan } \\
\text { Professional library staff included in faculty re- } \\
\text { tirement plan } \\
\text { Clerical library staff included in faculty retire- } \\
\text { ment plan } \\
\text { Chief librarians only included } \\
\text { Separate plan for professional staff } \\
\text { Separate plan for clerical staff } \\
\text { Compulsory participation-institutions with re- } \\
\text { tirement plan } \\
\text { Voluntary participation-institutions with re- } \\
\text { tirement plan }\end{array}$ & $\begin{array}{r}41 \\
27 \\
10 \\
7 \\
28 \\
2 \\
8 \\
\\
29 \\
22 \\
1 \\
0 \\
2 \\
30 \\
\\
4\end{array}$ & $\begin{array}{r}66 \\
24 \\
17 \\
74 \\
5 \\
51 \\
21 \\
70 \\
\\
54 \\
2 \\
0 \\
5 \\
79 \\
11\end{array}$ & $\begin{array}{r}194 \\
115 \\
35 \\
44 \\
\text { I } \\
102 \\
33 \\
123 \\
45 \\
12 \\
9 \\
8 \\
80 \\
\\
54\end{array}$ & $\begin{array}{r}59 \\
18 \\
23 \\
1 \\
75 \\
24 \\
63 \\
23 \\
6 \\
5 \\
4 \\
59 \\
39\end{array}$ \\
\hline
\end{tabular}

The interpretation of the answers to this question presented some difficulties. Only those institutions were counted as having faculty or administrative status which assigned it to half or more of the professional staff. Their classification can have a very important bearing on their eligibility to participate in retirement plans. Greenough reports, for example, that about 16 per cent of the institutions using T.I.A.A. plans restrict coverage to faculty. Another 58 per cent limit coverage to faculty and administrative officers, while only some 26 per cent provide coverage for substantially all employees. $^{7}$

The clerk on the library staff enjoys the right to participate in a retirement plan much less frequently than the professional

T Greenough, op. cit., p. 233 . leges answering the questionnaires reported the smallest percentage of plans covering library clerks.

O. C. Carmichael, in his foreword to Greenough's book, says :

While a large proportion of the colleges and universities of the United States and Canada have plans for the retirement of professors, relatively few make provision for the nonacademic staffs of their institutions ... In view of the social security laws that compel business and industry to provide for their employees, it is becoming more and more obvious that institutions which are not covered by these laws must make some provision for all their workers. ${ }^{8}$

Although the library clerk may now be denied participation in retirement plans in a

s Ibid., p. vii. 
Table IV

State Teachers Colleges

\begin{tabular}{|c|c|c|}
\hline & $\begin{array}{c}\text { Num- } \\
\text { ber }\end{array}$ & $\underset{\text { Cent }}{\text { Per }}$ \\
\hline $\begin{array}{l}\text { Institutions replying } \\
\text { Faculty status for librarians } \\
\text { Administrative officer status for }\end{array}$ & $\begin{array}{l}39 \\
24\end{array}$ & $\begin{array}{l}19 \\
61\end{array}$ \\
\hline librarians, but not faculty & 8 & 22 \\
\hline $\begin{array}{l}\text { No retirement plan for faculty } \\
\text { Retirement plan for faculty }\end{array}$ & 5 & 13 \\
\hline $\begin{array}{l}\text { State plan } \\
\text { T.I.A.A. plan } \\
\text { Other plan }\end{array}$ & $\begin{array}{r}28 \\
3 \\
2\end{array}$ & $\begin{array}{r}85 \\
9 \\
6\end{array}$ \\
\hline $\begin{array}{l}\text { Professional library staff in- } \\
\text { cluded in faculty retirement } \\
\text { plan } \\
\text { Clerical library staff included }\end{array}$ & 32 & 82 \\
\hline in faculty retirement plan & I6 & $4^{I}$ \\
\hline $\begin{array}{l}\text { Chief librarians only included } \\
\text { Separate plan for professional } \\
\text { staff }\end{array}$ & I & 3 \\
\hline $\begin{array}{l}\text { Separate plan for clerical staff } \\
\text { Compulsory participation-in- } \\
\text { stitutions with retirement plan }\end{array}$ & 24 & 5 \\
\hline $\begin{array}{l}\text { Voluntary participation - insti- } \\
\text { tutions with retirement plan }\end{array}$ & 4 & 12 \\
\hline
\end{tabular}

large majority of colleges and universities, the outlook for the future is good.

Today most new retirement plans cover all academic staff members ... and a growing number include all employees. College officers are now studying the problems of coverage of nonacademic employees. ${ }^{9}$

There seems little doubt that most college officers are convinced of the necessity for providing retirement plans. Returns to the questionnaire indicate that there has been a gradual growth of the movement among private institutions since 1900 , with a slight acceleration during the last two decades. Among public institutions, most of the plans were adopted since 1930. During the past few years many institutions have revised plans adopted earlier to provide greater benefits and more extensive coverage. The concept of social security seems to be fairly generally accepted by the American people, and further developments in the college and university field can be expected.

\footnotetext{
Ibid., p. 31 .
}

Table V

Professional and Technical Schools

\begin{tabular}{|c|c|c|}
\hline & $\begin{array}{l}\text { Num- } \\
\text { ber }\end{array}$ & $\begin{array}{l}\text { Per } \\
\text { Cent }\end{array}$ \\
\hline Institutions replying & 29 & 1. II \\
\hline Faculty status for librarians & 13 & 45 \\
\hline $\begin{array}{l}\text { Administrative officer status for } \\
\text { librarians, but not faculty }\end{array}$ & 8 & 27 \\
\hline $\begin{array}{l}\text { No retirement plan for faculty } \\
\text { Retirement plan for faculty }\end{array}$ & Io & 34 \\
\hline State plan & $\circ$ & 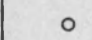 \\
\hline $\begin{array}{l}\text { T.I.A.A. plan } \\
\text { Other plan }\end{array}$ & $\begin{array}{r}6 \\
12\end{array}$ & $\begin{array}{l}33 \\
67\end{array}$ \\
\hline $\begin{array}{l}\text { Professional library staff in- } \\
\text { cluded in faculty retirement } \\
\text { plan }\end{array}$ & & \\
\hline Clerical library staff included & I7 & 58 \\
\hline in faculty retirement plan & I I & 38 \\
\hline $\begin{array}{l}\text { Chief librarians only included } \\
\text { Separate plan for professional } \\
\text { staff }\end{array}$ & I & 0 \\
\hline $\begin{array}{l}\text { Separate plan for clerical staff } \\
\text { Compulsory participation-in- }\end{array}$ & I & 3 \\
\hline $\begin{array}{l}\text { stitutions with retirement plan } \\
\text { Voluntary participation - insti- }\end{array}$ & 9 & 50 \\
\hline tutions with retirement plan & IO & 55 \\
\hline
\end{tabular}

The problem is largely one of ways and means. In this connection, the legislation now pending before Congress to extend the Federal Social Security Act is important. Participation in this program by colleges and universities may be the answer to the problem of librarians and particularly of clerks who are not now covered in other ways. Mobility of clerks is usually from one clerical position to another within the same community, rather than from one college to another. The Federal Social Security Act is, therefore, better adapted to the retirement needs of this group. It should be noted, however, that the proposed extension of the act makes participation by nonprofit educational institutions voluntary rather than compulsory. ${ }^{10}$

The conditions under which faculty, librarians, and others participate in retirement plans are analyzed in detail by Greenough. ${ }^{11}$ Two questions seem to be particularly crucial at the present time: (I)

10 New York Times, Aug. 9, 1949, p. I, 18.

11 Op. cit., p. 77-180. 
the adequacy of benefits, and (2) the forfeiture provisions of many plans. The objectives of a retirement plan are defeated unless the individual is assured an adequate income when he reaches retirement age.

A large majority of the fixed contribution plans require contributions of 5 percent of salary from the participant and 5 percent from the institution, rates that no longer
Greenough. ${ }^{13} \quad \mathrm{He}$ definitely advocates a contract system like that of T.I.A.A., whereby the individual retains the value of all contributions made on his behalf, but cannot cash or otherwise defeat the purpose of his contract.

The library staff offers many of the same personnel problems as the faculty. Too little or too much turnover are both unde-

Table VI

Junior Colleges

\begin{tabular}{|c|c|c|c|c|}
\hline & Number & Per Cent & $\begin{array}{l}\text { Pri } \\
\text { Number }\end{array}$ & Per Cent \\
\hline $\begin{array}{l}\text { Institutions replying } \\
\text { Faculty status for librarians } \\
\text { Administrative officer status for librarians, but } \\
\text { not faculty } \\
\text { No retirement plan for faculty } \\
\text { Retirement plan for faculty } \\
\text { State plan } \\
\text { T.I.A.A. plan } \\
\text { Other plan } \\
\text { Professional library staff included in faculty re- } \\
\text { tirement plan } \\
\text { Clerical library staff included in faculty retire- } \\
\text { ment plan } \\
\text { Chief librarians only included } \\
\text { Separate plan for professional staff } \\
\text { Separate plan for clerical staff } \\
\text { Compulsory participation-institutions with re- } \\
\text { ment plan } \\
\text { Voluntary participation-institutions with re- } \\
\text { tirement plan }\end{array}$ & $\begin{array}{r}15 \\
14 \\
1 \\
2 \\
7 \\
2 \\
1 \\
11 \\
11 \\
4 \\
0 \\
2 \\
1 \\
11 \\
11 \\
0\end{array}$ & $\begin{array}{r}93 \\
7 \\
11 \\
70 \\
20 \\
10 \\
\\
73 \\
27 \\
0 \\
13 \\
6 \\
74 \\
74 \\
0\end{array}$ & $\begin{array}{r}19 \\
15 \\
1 \\
10 \\
0 \\
4 \\
4 \\
9 \\
5 \\
0 \\
0 \\
0 \\
5 \\
3 \\
3\end{array}$ & $\begin{array}{r}79 \\
5 \\
53 \\
0 \\
50 \\
50 \\
47 \\
26 \\
0 \\
0 \\
0 \\
63 \\
38\end{array}$ \\
\hline
\end{tabular}

produce reasonably adequate retiring allowances. Likewise, the majority of fixed benefit plans establish a ceiling on benefits that is too low to meet the needs of retiring college teachers. ${ }^{12}$

Most of the publicly administered plans, nonfunded, and self-funded plans, include forfeiture provisions. If the employee severs his connection with the institution he is usually forced to cash in the accumulation set aside during employment for his retirement, and he usually forfeits the amounts contributed by the employer. The adverse effects of these provisions upon recruiting, mobility of personnel, and retention of second-rate employees are carefully listed by

12 Ibid., p. 39. sirable. Greenough's arguments for the contract type of retirement plan without forfeiture clauses are difficult to refute. It seems likely that most college and university library staffs could be strengthened more easily and more quickly if librarians were universally entitled to participate in a contract type of retirement system.

It is interesting to note the extent to which eligible librarians have chosen to participate in voluntary plans. In 50 per cent of the private institutions with such voluntary participation, half or more of the librarians are acquiring retirement protection. In nine per cent of the public institutions with voluntary plans, half or more

${ }^{13}$ Ibid., p. 42-47. 
of the librarians have chosen to participate. These facts seem to support Greenough's statement that "the experience of colleges with no retirement plans or with voluntary plans shows that it is wishful thinking to believe that all or even a substantial portion of college staff members will make adequate provision for their old age if left to their own devices."14

The answers to the final question- "Do you consider your retirement plan an asset in attracting the type of staff member you want for the library?"--revealed interesting reactions that cannot easily be tabualted. Many librarians responded with much more than a plain "yes" or "no." In general, about three-fourths replied in the affirmative. Some felt so strongly on the subject that they apparently considered the question superfluous. There are apparently two major reasons for a negative answer to this question: ( $I$ ) the plan itself is unsatisfactory, particularly with regard to adequacy of retirement income; (2) the younger li-

14 Ibid., p. 32. brarian at the beginning of his career is not particularly concerned about retirement. The fact that the majority of beginning librarians are young women makes the effect of the second factor even stronger.

To summarize, the professional library staff is eligible to participate in the retirement plans of about three-fourths of the institutions which have them for faculty. Plans covering librarians are probably available in a little less than one-half of all the four-year institutions of higher education in the United States. These institutions, however, probably employ about 80 per cent of all college and university librarians. In about 40 per cent of the institutions with retirement plans, library clerks are eligible to participate. Publicly supported institutions provide retirement for librarians and clerks more often than private, but almost all their plans include forfeiture provisions. Much work still needs to be done in extending coverage of retirement plans and particularly in improving the benefits and conditions of participation.

\section{Appendix I}

\section{Sample Questionaire}

\section{AMERICAN LIBRARY ASSOCIATION}

COMMITTEE ON ANNUITIES, PENSIONS AND LIFE INSURANCE

Name of library

Answered by:

Title

I. Size of staff (do not include student assistants) : Professional ....... Clerical .......

2. Does the professional staff have academic rank? Yes ..... No ..... Are professional staff members classified as "administrative officers"? Yes ..... No .....

3. Does your institution have a retirement plan for the faculty? Yes ..... No ..... When was it adopted?

4. (a) Is the professional library staff eligible to participate in this plan? Yes $\ldots .$. No ..... Is the clerical staff eligible to participate? Yes ..... No ..... When was the plan made available to professional staff members? To clerical staff?

(b) Is there a separate retirement plan for the professional library staff? Yes ..... No ..... When was it adopted? Is there a separate plan for the clerical staff? Yes ...... No ..... When was it adopted? 
5. What are the conditions of participation: voluntary or compulsory; age limit; rank, etc.?

6. Is there a waiting period for participation? Yes ..... No ..... How long (in years)?

7. How many library staff members are now participating in the retirement plan? Professional ....... Clerical ....... How many retired staff members are now drawing benefits from the plan? Professional ....... Clerical .......

8. What is the retirement age for professional library staff? Voluntary ....... Compulsory ....... What is the retirement age for clerical staff? Voluntary ....... Compulsory ........ Is retirement possible for disability? Under what conditions?

9. Describe briefly your retirement plan. If you prefer, use the back of the sheet to answer this question.

\section{a. CONTRIBUTORY}

What per cent is contributed by the staff member? ........

What per cent is contributed by the institution? .........

Is there a limit on the institution's contributions? ...... If so, how much? ......

b. NON-CONTRIBUTORY

Does the institution contribute the entire amount?

Does the individual contribute the entire amount?

How are retirement benefits determined?

c. CONTRACTS

Do you use Teachers Insurance and Annuity Association annuity contracts? .......

Do you use annuity contracts with another insurance company?.......

Do you accumulate your own funds? ........

Is your plan part of a retirement system for public employees? ..... State ......; Municipal ......; County .....; Special group of educational employees in the city or state ........

Is your plan part of a retirement system for religious workers?

\section{d. BENEFITS}

How are benefits determined?

Are death benefits available?

Are any supplementary benefits available, e.g., adjustments for employees who are within a few years of retirement age at the time the plan was adopted?

What provision is made for the employee who leaves the service of the institution before reaching retirement age?

Io. Do you consider your retirement plan an asset in attracting the type of staff member you want for the library? 